\title{
Muerte y pérdida de identidad. Temor que despiertan en la sociedad castellana durante la Baja Edad Media*
}

\author{
Death, Loss of Identity and the Fear They Evoke in Castilian \\ Society During the Later Middle Ages
}

\begin{abstract}
Ana R. RABAZO VinaGRE**
RESUMEN ABSTRACT

Uno de los modos de conocer las mentalidades de una sociedad es a través del análisis de sus sentimientos. Este estudio se centra en dos de los temores a los que se enfrentan los habitantes de Castilla en la Baja Edad Media, la muerte y la pérdida de identidad, a través de su relación y su proyección material, tanto literaria como iconográfica. El contexto temporal coincide con las transformaciones de la decimoquinta centuria, lo que supone un cambio en la

One of the ways to approach the study of mentalities is through the analysis of human feelings. This study examines death and the loss of identity, two common fears in Castile in the Later Middle Ages, through their relationship and material expression, both literary and iconographic. Our focus will be on the fifteenth century, a time of deep transformations in which we encounter a shift in the meaning of these two aspects of life and, thus, of the fear they evoke.
\end{abstract} concepción de estos dos aspectos de la vida $y$, por ende, del miedo que suscitan.

\section{PALABRAS CLAVE}

Muerte, miedo, identidad, fuentes, Castilla,

Baja Edad Media.

\section{KEY WORDS}

Death, fear, identity, sources, Castile, Late Middle Ages.

\section{INTRODUCCIÓN}

Dediqué mi tesis doctoral al estudio del sentimiento del miedo y su proyección en las fuentes castellanas, ya que los temores reflejan las creencias que conforman la mentalidad de los habitantes del Medioevo, determinando las acciones y las actitudes de sus gentes, además de convertirse en un medio de control no sólo cultural, sino también social y económico ${ }^{1}$. No pretendía limitarme a la enumeración

* Fecha de recepción del artículo: 2011-1-16. Fecha de aceptación del artículo: 2011-3-16.

** Doctora en Historia Medieval. UNED. C.e.: anetxu@gmail.com

1 «El miedo y su expresión en las fuentes medievales. Mentalidades y sociedad en el reino de Castilla» UNED, febrero 2010. 
de temas que provocan angustia en general en el ser humano, como la enfermedad, la muerte, los castigos, las penas infernales, los demonios, las minorías, la violencia y las guerras, las epidemias..., sino al análisis de aquello que refleja el miedo y que ha perdurado en las fuentes hasta nuestros días, como las creencias mágico-supersticiosas, leyendas y mitos, rituales, símbolos, preceptos cristianos, representaciones iconográficas... etc.

El artículo sigue esta línea de análisis, pero centrado en dos temas concretos y en la relación entre ambos: la muerte y la pérdida de identidad. Este último es uno de los que más desapercibido suele pasar al estudiar las mentalidades de la sociedad medieval, no concediéndosele, con frecuencia, la importancia que merece $^{2}$.

\section{EL MIEDO COMO INSTRUMENTO PARA EL ESTUDIO DE LA HISTORIA DE LAS MENTALIDADES}

Aunque innato en el ser humano, el miedo despierta ante una amenaza, alterando el estadio de seguridad del individuo y atacando su instinto de supervivencia. Existen desencadenantes universales y otros propios de cada periodo histórico; quizá sería más apropiado señalar que existen desencadenantes de mayor repercusión en una determinada época, debido a factores contextuales. Desde el punto de vista psicológico, los principales temores son aquellos que nacen en el interior del inconsciente humano y de ellos surgen los demás adquiriendo formas y motivos diversos; esto explica que se repitan en el espacio y en el tiempo en diferentes culturas. Sin embargo, su prevención y representación quedan marcadas por la etapa en la que se desarrolla, ya que son determinadas por las creencias y por la cultu-

\footnotetext{
2 Haciendo un breve apunte sobre el estado de la cuestión, debemos mencionar que son numerosos los trabajos que tratan acerca del tema de la muerte en la Edad Media y todo lo que está relacionado con ella en la mentalidad del individuo en general, y en la del hombre de la Edad Media en particular. Philippe ARIÈS dedicó a esta materia un estudio de obligada lectura para abordar este tema, titulado Historia de la muerte en Occidente. Desde la Edad Media hasta nuestros días (hay edición reciente en Barcelona, El Acantilado, 28, 2000). Entre los historiadores españoles es un reconocido especialista el profesor Emilio MITRE, a quien he seguido en algunas de sus teorías expuestas en varios de sus estudios, como los titulados «Las actitudes del hombre ante la muerte», en César GONZÁLEZ MíNGUEZ (Ed.), La otra historia. Sociedad, cultura y mentalidades (Vitoria, UPV, 1993, pp. 25-36), o Fantasmas de la sociedad medieval. Enfermedad. Peste. Muerte (Universidad de Valladolid, 2004); este mismo autor colaboró en una obra especialmente relevante en torno a este tema editada por Eliseo SERRANO MARTíN, titulada Muerte, religiosidad y cultura popular. Siglos XIII-XVIII (Zaragoza, Institución Fernando el Católico, 1994). Pero especial mención merece el libro de Fernando MARTÍNEZ GIL, La muerte vivida. Muerte y sociedad en Castilla durante la Baja Edad Media (Diputación Provincial de Toledo y Universidad de Castilla-La Mancha, 1996), por su contenido y por la forma en la que elabora la información. En el aspecto iconográfico, merece ser reseñado, entre otros, el estudio de Ángela FRANCO MATA, «Encuentro de los tres vivos y los tres muertos y las danzas de la muerte», en Boletín del Museo de Arqueología Nacional, nํ20, Madrid, 2002, pp. 173-214. Son asimismo de obligada referencia las obras de Jean DELUMEAU, El miedo en Occidente (Madrid, Taurus, 1989) y de Georges DUBY, Año 1000, año 2000. La huella de nuestros miedos (Santiago de Chile, Andrés Bello, 1995), ya que ambas abordan como tema principal el sentimiento del miedo en los diferentes aspectos de la vida medieval.
} 
ra del momento y del ámbito geográfico, en este caso la Baja Edad Media en el reino castellano.

La naturaleza del miedo puede servirnos para desfragmentar las características de la sociedad medieval en relación con el individuo, en el contexto en el que tiene desarrollo, y su grado de influencia. Por un lado, desde el punto de vista social, las experiencias, la educación, los valores esperados dentro de cada estado, establecen la importancia de los miedos dentro de las diferentes escalas de la sociedad; el pulso entre la nobleza y la burguesía, grupo cuyo valor se ve incrementado por el desarrollo del mundo urbano en detrimento del rural, se saldará con el acomodo de todos los aspectos de la vida cotidiana a esta nueva realidad social, indisolublemente ligada también a la economía y la política y, por ende, a la cultura y su proyección ideológica y material. Desde el punto de vista filosófico, el desarrollo del individualismo frente al sentimiento colectivo de los comienzos de la etapa marca la tendencia también en el tipo de miedo de cada individuo. Además, hay que tener en cuenta que, si bien los temores pueden ser los mismos, dentro de cada grupo social varía el riesgo, la peligrosidad y la tendencia a sufrir el desencadenante de ese temor.

El modo y la finalidad de la transmisión son de suma importancia. Muchos de ellos se asientan mediante endoculturación. En este caso, suele tratarse de una transferencia inconsciente, formando parte de las creencias, del carácter y los valores que va a recibir el individuo dentro del seno familiar o de la comunidad. En no pocas ocasiones, las experiencias vividas por los antecesores demarcan el modo, la forma y la importancia que los caracteriza. Las generaciones que suceden a los afectados por epidemias, episodios de graves hambrunas o acontecimientos bélicos desgarradores, transmiten un miedo particular. Estos hechos van fraguando la mentalidad propia medieval, y otorgan características también diferentes al periodo y al ámbito geográfico. Sin embargo, existe otra vía de enseñanza: las fuentes iconográficas, literarias, los dogmas cristianos, doctrinales, legislaciones sobre diversos temas... etc., por lo que es indispensable el estudio de las fuentes que han llegado hasta nosotros.

Al analizar los miedos y su representación cultural debemos atender a su naturaleza, ya que existen diferentes tipologías. Por un lado nos encontramos con los temores circunstanciales, aquellos que vienen de la mano de un contexto concreto, puntual, derivados de una realidad latente. Alteran la armonía del colectivo medieval, rompiendo con la cotidianidad, hecho que tiene repercusiones en una sociedad tan ligada a sus costumbres, tanto en su vida diaria como en su comportamiento, especialmente en momentos y en lugares con contactos y medios de comunicación más limitados. Otros, por contra, no responden a una amenaza real o inmediata, sino que configuran en la psique colectiva del Medioevo un sentimiento de angustia constante; entre ellos se situarían la muerte y la pérdida de identidad, los dos temas que nos ocupan. 
Se podría añadir aquello a lo que se teme, una amenaza constante, pero no real o a priori, no verificada. Me refiero a todo el ámbito del temor a lo numinoso, que va desde el terror que provocan la divinidad, las penas, el infierno o el juicio final, sea universal o individual, pasando por el miedo al pecado, a las apariciones, a los fantasmas, a los monstruos, etc., y una de las mayores consecuencias que trae consigo, la superstición. Son especialmente utilizados como medio de control de la voluntad social, dado su carácter enigmático. La doble naturaleza que alberga toda creencia hace complejo el análisis de lo temporal y lo espiritual de un modo independiente; incluso, en ocasiones, ambas realidades se funden dando lugar a miedos de doble carácter.

Existe un miedo recurrente que se repite en la gran mayoría de los temores del individuo medieval, bien directamente o llevándolo implícito en él: la pérdida de identidad. Desde el punto de vista antropológico, el ser humano es un ser dotado de identidad. Ortega y Gasset afirmaba que "Yo soy yo y mi circunstancia y si no la salvo a ella no me salvo yo ${ }^{3}$, haciendo girar su teoría filosófica alrededor de esta máxima. Una base muy similar es la que encontramos en la conciencia de cada componente de la sociedad medieval.

Determinado desde el momento del nacimiento, el hombre del Medioevo moldea su carácter y su vida en torno a una serie de derechos y deberes que le vienen dados con su identidad. Su cotidianidad está marcada por todo este complejo de códigos, tanto civiles como religiosos. Establecen deberes a la hora de actuar, de vivir y de morir. En una sociedad mucho más acostumbrada al dolor, a la violencia, al sufrimiento... ¿qué puede provocar más temor? Pues el ser expulsado y repudiado por la familia, por la comunidad, tanto civil como religiosa. Lo mismo ocurre con la muerte y la salvación del alma, a las que se tiene acceso dentro de un código de acciones determinados por la identidad; si ésta se pierde, ¿cómo obtendrán este galardón?

De hecho, los castigos que conllevan una pérdida de identidad, la excomunión o el destierro, son los más temidos; suponen la pena máxima, que incluye la deshonra del individuo y de su linaje. La excomunión supone una pérdida de identidad tanto espiritual como civil. Se aplica en casos extremos y, con la amenaza de tal sanción, se apacigua la intención de cometer un acto prohibido. Este castigo no es únicamente de índole religioso. Es cierto que la pérdida de cualquier beneficio divino, como el enterramiento fuera de sagrado, la salvación del alma y el acceso al paraíso celestial, fundamenta la fuerza y la crueldad de esta sanción. Sin embargo, las consecuencias sociales que debía sufrir podrían ser más indeseadas.

Siguiendo esta línea de carácter religioso-salvífico, se recoge en las fuentes medievales otra alusión a la pérdida de identidad y a la condena del creyente tras su muerte: la venta del alma al demonio. Este hecho reconoce la potestad que

3 José ORTEGA Y GASSET, Meditaciones del Quijote. Madrid, Cátedra, 1984. En la Introducción de esta obra se explica la tesis filosófica del pensador madrileño. 
cada individuo posee sobre el destino de su alma, determinado por las acciones y decisiones tomadas en la vida terrena. La obra de Alfonso X el Sabio en honor a Santa María dedica una Cantiga a la Leyenda de Teófilot. Este tema será posteriormente retomado, por ejemplo, en el Fausto de Goethe.

Dejando a un lado el aspecto religioso, el hombre medieval, como ser social, necesita pertenecer a un grupo y teme las consecuencias que supone su expulsión de la sociedad, su destierro, especialmente entre la nobleza. Un individuo pierde todo aquello que le ha caracterizado durante ese momento: bienes, poder político y prestigio social, lo que se hace extensivo a todo el linaje. Noel Fallows, en su obra sobre los tratados de Alonso de Cartagena, pone el acento en esta idea del destierro y su tremendo significado para el caballero medieval, aludiendo a las palabras de Alfonso X en Las Siete Partidas, donde se considera al destierro como «muerte civil» 5 . Esto nos ayuda a hacernos una idea del temor que infunde esta pena, así como la diversa interpretación de la muerte en la Edad Media, que no se limita a la física, sino que abarca un sinfín de ámbitos civiles y metafísicos.

En este estudio pretendo analizar su vinculación con el miedo a la muerte, hecho que suele pasarse por alto pero que merece ser reseñado para entender las mentalidades ante la muerte y la pérdida de identidad, así como su desarrollo cultural.

\section{La historia de las mentalidades y los miedos}

La investigación de la historia de la cultura y de las mentalidades resulta compleja por la dificultad de su interpretación y la limitación de los apoyos con los que sustentar posibles conclusiones. Tanto es así que han surgido estudios y nuevas formas de acercamiento a la historia que abordan distintas temáticas de un modo menos tradicional, utilizando todas las disciplinas al alcance del investigador: antropología, arte, arqueología, literatura, historia..., y las fuentes que estas ofrecen para, mediante su análisis, elaborar un discurso completo en busca de conclusiones sobre la realidad del hombre, en este caso en un periodo y territorio concretos, en base a aquello que lo refleja de un modo material, cultural, además de aquello que lo caracteriza como hombre.

Hay que tener en cuenta el contacto e influencia entre las culturas colindantes, en cuanto a formas y contenidos, así como la supervivencia de culturas anteriores, aunque modeladas para hacerlas más comprensibles al nuevo discurso cristiano. Lo mismo ocurre con las creencias que se extienden por la geografía europea medieval y a través del tiempo, con el mantenimiento de otras ancestrales adecuadas

\footnotetext{
4 Se trata de la Cantiga número III: Teófilo aparece donando, mediante un documento escrito, su alma al mismísimo diablo, siendo la Virgen quien debe interceder para salvar al fiel.

5 Alonso de CARTAGENA, Doctrinal de caballeros; Tratado de la guerra; Dichos de Quinto Curcio. Edición de Noel Fallows, Ministerio de Defensa, 2006, p. 34.
} 
a la nueva realidad, con ciertas peculiaridades locales y temporales que reflejan cada etapa. También se suceden cambios y apuntes evolutivos, no sólo condicionados por cada contexto histórico, sino especialmente por la ampliación de emisores y receptores en el mundo cultural al final del periodo. En cuanto a los medios culturales, el contenido y continente suele ser variado y viene determinado por el público, ya que se pretende que el mensaje pueda ser interpretado por él. De ahí que en los primeros tiempos de la Edad Media se mantengan formas antiguas, modelando los nuevos preceptos que, al ser de tradición rural, gozan de un marcado carácter natural, evolucionando hacia formas más propias de la vida cotidiana urbana, de los frentes de poder, de la vida mundana en general, en los últimos tiempos medievales. La cultura escrita estuvo muy limitada hasta el fin de la Edad Media, en tanto que de la tradición oral, pese a su importancia, apenas han quedado testimonios; no obstante, los testimonios que perviven ofrecen una visión particular de la sociedad y sus creencias, de lo que son un buen ejemplo los sermones de San Vicente Ferrer. Además, hay que pensar que buena parte de la cultura escrita tiene su inicio en la tradición oral, por lo que se mantuvo viva y se mantiene en estos testimonios. Por otro lado, las formas iconográficas son numerosas, aunque nos encontramos con la dificultad y, en no pocas ocasiones, con la ambigüedad interpretativa que entraña su análisis, lo que plantea la duda de si el creyente fue capaz de entender plenamente el mensaje que se deseaba transmitir; por tanto, es dudoso el valor dogmático real que tenían en este periodo.

\section{REPRESENTACIÓN DE LA MUERTE EN LAS FUENTES. REFLEJO DEL MIEDO QUE SUSCITA}

La muerte se rodea de un sinfín de símbolos, que nos evocan la dimensión y significado que fue adquiriendo durante la Edad Media, así como las transformaciones que van sucediéndose hasta desembocar en un cambio ideológico, más notorio ya en la decimoquinta centuria. Historiadores y antropólogos han insistido en la relevancia del estudio de los comportamientos y actitudes de una sociedad ante la muerte para entender y comprender su mentalidad.

El miedo a la muerte y a los muertos comprende un entramado amplísimo de creencias, de ceremonias y de representaciones, que toma forma y evoluciona al tiempo que lo hacen los habitantes del Medioevo. Ritos funerarios más o menos dramáticos, apariciones de muertos a vivos, debate sobre el lugar de descanso y socialización de la muerte son algunas de las cuestiones que serán tratadas en este apartado.

La muerte, junto con el pecado, es uno de los pilares sobre el que se asientan las preocupaciones de la sociedad, individualizándose y correlacionándose de un modo más manifiesto a fines de la Edad Media. La inquietud por la muerte y sus consecuencias ha afectado a todos los seres humanos desde tiempos ancestrales, debido tanto al desconocimiento como al dolor que supone; la idea de viaje a un 
destino inédito, la resurrección en otro mundo..., y, en definitiva, los diferentes modos y porqués de su interpretación, son particularidades de las diversas creencias que se han desarrollado en todos los marcos espacio-temporales. Para el periodo que nos ocupa es reveladora la importancia que adquiere la buena muerte, para entender un poco mejor el miedo que provoca en el habitante del Medioevo. En la Baja Edad Media se multiplican las obras sobre esta temática; son, por ejemplo, los libros sobre el arte del bien morir y los penitenciales y manuales de Confesión, así como otros referentes al paso que supone la muerte, como son los libros de horas, o motivos iconográficos como la danza de la muerte ${ }^{7}$.

El poder ejemplificador del individuo del Medioevo no sólo se limita a la vida, sino al paso que supone la muerte. Es decir, en una sociedad en la que la dimensión temporal parece carecer de importancia, este momento adquiere un valor fundamental. Se une a esta actitud ante la muerte el sentimiento de rechazo al mundo sensible, que repetimos una y otra vez con respecto a los individuos medievales, de donde deriva su importancia y el temor a no estar a la altura que se requiere.

\section{Concepción y proyección material}

La muerte requiere un tratamiento especial, por lo que goza de constituciones y disposiciones que la regulan: redoblar de campanas, cortejos fúnebres que acompañan con llantos y gritos al finado hasta la iglesia, responsorios, enterramiento en el cementerio, misas y aniversarios, etc. Un sinfín de actos que envuelven de simbolismo esta acción natural y esconden el miedo que despierta. Este temor, y el cumplimiento de una serie de rituales por parte del finado y su familia, son aprovechados para articular a su alrededor una red de obligaciones, tanto sociales como económicas, de enorme importancia. En las postrimerías de la Edad Media, los Reyes Católicos tratan de establecer unas pautas en relación con la muerte que habrían de ser seguidas en la totalidad del reino, no sólo desde el punto de vista económico, sino también social y cultural, todo ello con la intención de evitar abusos. En épocas de elevada mortalidad, como en tiempos de epidemias, la imposibilidad de seguir este protocolo de forma metódica refleja la crudeza del momento que se vive, y acrecienta más si cabe el miedo a perecer. Las exequias, responsos, vigilias, misas, entierro con la cruz, aniversarios, ceremonias anuales y votivas e, incluso, aniversarios perpetuos, que ha dispuesto en testamento el finado reflejan la

${ }^{6}$ Una completa relación de esta tipología la encontramos en el artículo de lldefonso ADEVA MARTíN «Los "Artes de bien morir" en España antes del maestro Venegas» en Scripta Theologica. Universidad de Navarra, 1984, Vol. 16 (1-2), pp. 405-415; También es reseñable el estudio de Fernando MARTíNEZ GIL, La muerte vivida. Muerte y sociedad en Castilla durante la Baja Edad Media, p. 135 y siguientes. Este último autor cita los ejemplos castellanos: Arte y doctrina de bien morir de la Biblioteca de El Escorial. El Art de bien morir, de la Biblioteca Nacional, manuscrito 6485, Biblioteca Nacional. Art de saber bien morir de la Biblioteca del Palacio Real.

7 El texto escrito lo podemos encontrar en La danza de la muerte. Edición de Sabas MARTíN. Madrid. Miraguano, 2001. 
preocupación que suscita este momento, dado el fin salvífico que se otorga a estos oficios. El precio a pagar es elevado, por lo que deben disponer de recursos suficientes para hacerle frente, o, en caso contrario, contar con la solidaridad de la comunidad a la que pertenecen, lo que explica el miedo a su exclusión, a la pérdida de la identidad que se le otorga por estar vinculado a ella.

El sentimiento que despierta la muerte en el ser humano es complejo y contradictorio. El dolor que provoca el fallecimiento de un ser querido es inmenso e incontrolable; es innato y perfectamente entendible. Las muestras visibles de sufrimiento de los veladores de un cadáver simbolizan el amor que se siente por el finado, la importancia que tiene en el seno de la comunidad y la desesperanza que invade el corazón de quienes van a tener que vivir con su ausencia. Estos gestos se dramatizan y pasan a formar parte del ceremonial funerario, porque no interesa ocultar la pena. Las procesiones de gritos, llantos, tirones de pelo y ropa o golpes faciales y corporales son parte de todos los actos que componen la despedida del difunto. Este tipo de conducta se contradice totalmente con la idea esperanzadora que, en relación con la muerte, contiene el mensaje cristiano, y supone un problema para el clero, que aboga por el control de ciertas actitudes de duelo exacerbado, criticando, por ejemplo, la figura de la plañidera o llorona, una de las encargadas de dramatizar estos sentimientos.

En la literatura medieval, en general, y en la poesía, en particular, encontramos un sinfín de descripciones sobre la muerte y la representación del dolor en la Edad Media. Sin embargo, desde los sectores intelectuales del cristianismo esta actitud se considera contraria a la idea de salvación futura, al desprecio por lo terreno y al deseo de morir como exigen los dogmas para obtener el preciado fin, la recompensa prometida, la gloria eterna. Estos actos no son propios de quienes han de demostrar júbilo por la marcha de un ser querido a la verdadera vida. Por todo ello, se pretende controlar los signos exagerados de dolor, mostrando a través de la iconografía y la literatura una idea de resurrección inminente y felicidad; del mismo modo, desde los medios de difusión orales se critican y controlan estas actitudes. Esta temática se extiende a los sepulcros, en los que vemos tanto el acto de duelo a izquierda y derecha como la elevación del ánima en el flanco central, encima de la representación del cuerpo yacente. Las figuras que se representan en estos duelos son de diferentes tamaños, simulando distintas edades, de ambos sexos, síntoma de la generalización de estas actitudes dentro de la sociedad, sin distinciones de ningún tipo.

Durante la Edad Media es un hecho incontestable la inminencia de la muerte. Puede llegar en el momento más insospechado, no atiende a razones de edad, se lleva a jóvenes y a viejos, y hay que cuidarse de que sorprenda en el mejor estado posible, pues en ese modo será juzgado y no volverá a tener una segunda oportunidad. Es relevante esta indicación que aparece, por ejemplo, en los Castigos y documentos del Rey Don Sancho, ya que en la época medieval castellana existe la creencia popular de que un hombre puede volver de la muerte con el fin de concluir 
un asunto pendiente, de pedir a sus familiares que rueguen por su alma o para consumar alguna obra que le garantice la salvación que parece habérsele negado: «[... quando omne deste mundo pasa para el otro non llieua consigo si non el bien que faze, ca sabe que nunca ha de tornar de alla [...] ",8. No aclara lo que ocurre con aquellos que no salvan su alma: ¿se mantiene la posibilidad de que aquel que no consiga la salvación retorne a este mundo suplicando honores que consigan liberar su alma?

Se pueden señalar dos tipos diferenciados de mala muerte. Por un lado la espiritual, que atañe a cada individuo, y que supone morir en pecado, sin confesión o sin arrepentimiento, teniendo que rendir cuentas a San Miguel. Por otra parte la propiamente física, aquella muerte que viene provocada por un acto que a los ojos de los demás individuos está fuera de la sacralidad y, por lo tanto, la condena se ejecuta sobre el finado en el ámbito terrenal (torneos, suicidios...).

La idea más reiterada en las fuentes literarias en el periodo que nos ocupa es la de la buena muerte. En la Baja Edad Media era tan relevante esta idea que se ponen en boga los Libros de Horas y la literatura sobre el arte del bien morir. Todas estas obras tienen como fin enseñar el modo más provechoso de fallecer para un cristiano. Nuevamente en los consejos de Sancho IV se advierte la importancia de cómo asista la muerte a un cristiano, pues en ese estado serán juzgados; así, dice que "[...] e otros muchos que estauan en mal estado y non se quieren conosçer a Dios de los pecados que han fecho y fazen y alcançales la muerte en este mal estado, asi son perdidos, segund la palabra que dixo nuestro señor Ihesuchristo en el euangelio: en qual estado te fallare la muerte, en tal te judgare [...]”?.

Por este motivo, hay que preservarse del pecado en todos los momentos de la vida para evitar perecer en mal estado, especialmente en una sociedad en la que la mortalidad es elevada, en la que abundan los periodos de crisis: enfermedades, hambres, guerras... Surge una duda razonable, que se deriva tanto de los ars moriendi como de la iconografía de sepulcros, cúspides de portadas góticas, miniaturas y frescos. En todas estas manifestaciones el alma es elevada al cielo por dos pequeños ángeles alados; el alma parece ser salvada, pero no ha sido juzgada ni pesada por San Miguel; en algunas ocasiones es la Virgen, reflejo del incremento de la devoción mariana, quien intercede por el fiel. En cualquier caso, el mensaje que ofrece este símbolo es más benévolo y tranquilizador que los anteriores, en los que se representaba la balanza y el ángel psicopompo a los pies de las penas infernales. El hecho final del juicio no ha variado, pero la imaginería se ha vuelto más piadosa con el fiel a medida que avanzamos en el tiempo.

Esta idea no queda limitada a las manifestaciones literarias y artísticas; en sus predicaciones por Castilla, el dominico fray Vicente Ferrer recuerda el valor y la im-

8 Castigos y documentos del Rey Don Sancho. Edición de Antonio RIVERA GARCíA, basada en el manuscrito de la biblioteca del Escorial, Z-III-4, para la Biblioteca Saavedra Fajardo, p. 140.

9 Castigos y documentos del Rey Don Sancho, Capítulo primero, p. 15. 
portancia de este tránsito, crucial en la vida del cristiano. Insiste en la idea de una muerte acorde con la conducta que se exige durante el resto de su existencia terrenal. Sin embargo, lo más sorprendente de la descripción de este instante es la crudeza que se le confiere, frente a la idea de paz y serenidad difundida anteriormente. Por un lado, en el nivel terrenal, el dolor físico es tremendo en el momento en el que el alma abandona el cuerpo. En realidad, no se trata de una idea propia del dominico, sino que es una creencia extendida en la medicina medieval; la enfermedad es el abandono del alma de una parte determinada del cuerpo, y ese es el motivo por el que duele; el alma evita el dolor, pues son incompatibles, y es la encargada de establecer el equilibrio. Por eso, en ausencia total del alma, el sufrimiento se hace patente. Por otro lado, en el plano espiritual, los diablos acechan el alma del finado al abandonar el cuerpo, para apresarla y someterla a los tormentos más atroces. Ejemplos iconográficos de todo ello aparecen en las Cantigas de Santa María, en las que se representan diablos que pretenden capturar el alma del finado tras su fallecimiento, siendo la Virgen la última mediadora para salvarla y resucitar al difunto; la Cantiga número XXVI narra el suceso de un peregrino que fallece de un modo repentino y cuya alma intentan apresar unos malvados seres alados, siendo salvaguardada en este caso por el Apóstol Santiago. En la Cantiga número XI un monje se ahoga y unos entes similares intentan apoderarse de su ánima. La Cantiga número XLV describe la disputa entre ángeles y demonios por el alma de un caballero.

También encontramos una miniatura simbólica muy ilustrativa en la Cantiga número LXXV, en la que se representan la buena y la mala muerte, respectivamente. El finado, que ha fallecido libre de pecado, es acompañado por ángeles en su lecho de muerte, y su lecho se cubre con un arco que simbolizaría la cúpula celeste. En cambio, el finado que muere en pecado está rodeado de seres oscuros, alados, con tridentes; se mantiene el arco polilobulado que enmarca el dibujo, aludiendo al mundo terreno, y los presentes mantienen el gesto típico de los duelos de tirarse de los pelos y llorar amargamente.

El ars moriendi es un género literario que se desarrolla al amparo de los nuevos ideales. Insiste en la necesidad de una buena muerte para lograr la salvación, y describe los últimos momentos del ser humano, en los que está en juego su destino final. Narra por un lado las tentaciones del diablo y su séquito de seres infernales y, a su lado, la victoria del ángel de Dios, con la presencia de Jesús, la Virgen y los santos ante el difunto para acompañarle en su lecho. Iconográficamente, se representan ambas escenas contrapuestas. Tenemos un ejemplo que ha llegado hasta nuestros días y que sirve para ilustrar la ideología que se difunde en este periodo; se trata del manuscrito de Zaragoza, de finales del siglo XV, que fue impreso con una serie de grabados que ilustran el texto ${ }^{10}$. Resulta revelador cómo las figuraciones de los demonios se representan a los pies de la cama, con dife-

10 Fernando MARTíNEZ GIL, La muerte vivida. Muerte y sociedad en Castilla durante la Baja Edad Media, pp. 140 y siguientes. 
rentes formas diabólicas. Las fauces infernales dan cobijo a todos estos seres. La imagen derecha alude a la salvación, y compone la escena un ángel en el centro de la misma. Llamativa es, sin duda, la caracterización del hombre que está a punto de fallecer, señalado mediante una extrema delgadez que se hace visible tanto en el torso como en la cara. Entre los presentes como vicarios de la gloria eterna, además del ángel que cuida del alma del finado, aparece Jesús, simbolizado con el nimbo cristológico, que muestra junto a él pequeños seres, como niños, que podrían representar las ánimas de otros fieles. La Virgen y un santo imberbe, San Juan, junto a Jesús, compondrían la Deesis, motivo muy generalizado en el arte escatológico, pues representa la intercesión y la piedad ante el juicio de estas ánimas que están a punto de abandonar su cuerpo material. Les acompañan otros santos e, incluso, un ave, que podría ser una paloma simbolizando el espíritu de Dios, o una tórtola, símbolo de la permanencia fiel a Cristo tras la muerte, a semejanza de la Iglesia.

Otros conjuntos iconográficos especiales que aparecen al final del periodo, y que describen el cambio de concepción de la muerte y su relación con la pérdida de identidad, son las danzas macabras, el Encuentro entre los tres vivientes y los tres muertos, el Transi y el Triunfo de la Muerte. Si bien siempre se han ligado con el gusto por lo macabro, a consecuencia del duro varapalo que sufrió la sociedad con la Peste Negra, en realidad van mucho más allá y nos sirven para ilustrar claramente valores de la mentalidad medieval, que tuvieron su difusión en la Corona de Castilla en la Baja Edad Media, y que son a la vez causa y efecto de los miedos de esta sociedad ${ }^{11}$.

En general, todas estas escenas son representaciones de la muerte. En algunos casos se personifica el paso del estado vivo al no vivo mediante un ente que viene a buscar al futuro finado; en otros casos se caracteriza el estado post mortem, y son los muertos quienes adoptan esta figura. En el Triunfo de la Muerte se personifica por medio del esqueleto al ente que viene en busca del individuo que pierde su condición, su identidad, quedando sometido a este cruel e irónico personaje que arranca la naturaleza del ser y precipita su destino. No hay unanimidad sobre si es un Triunfo o una Danza de la Muerte lo que se representa en el claustro de la catedral de León; lo importante es que la idea general a la que se refieren ambos recursos iconográficos y, por ende, sus mensajes, era conocida en el periodo bajomedieval castellano.

El Transi es la encarnación del difunto, su nueva identidad, pero no del modo que se acostumbraba en la Edad Media, sino de un modo vital, en actitud todavía mortal y con su aspecto físico anterior al fallecimiento. Se muestran en actitud orante, leyendo o inertes, pero con los atributos que les han identificado en la vida: cetro, espada... El Transi es el cuerpo en descomposición, es la realidad de

11 Véase sobre este particular el excelente estudio de Ángela FRANCO MATA, «Encuentro de los tres vivos y los tres muertos y las danzas de la muerte», en Boletín del Museo Arqueológico Nacional, $\mathrm{n}^{\circ}$ 20, 2002, pp. 173-214. 
lo que se es tras la muerte, es el fin de la identidad anterior. Desaparecen atributos especiales, que otorgan una propiedad especial y prestigio social; es la igualdad a la que apuntan las Danzas Macabras. Cada uno con su igual, con su doble, que es un cuerpo en descomposición, desnudo, que no se puede diferenciar de los demás. En ocasiones se ha creído que el esqueleto o el cuerpo más o menos descarnado que acompaña a los vivos en estas danzas era la personificación de la muerte, pero podría ser, en realidad, el doble del vivo pero ya fallecido; es su reflejo tras la muerte, es el futuro que le espera. Esta idea también podemos relacionarla con el miedo al doble, a los reflejos de uno mismo, que se tenía en la Edad Media, como en otras diversas culturas, como símbolo en no pocas ocasiones de lo maléfico, y que en este caso manifiestan la muerte. Los muertos de la leyenda de los Tres vivientes representan la fugacidad de la vida, la banalidad de lo material lejos del mundo terrenal, el deber de guardar lo que se espera del individuo más allá de este corto camino dentro de la eternidad. Esta tradición se alarga en el tiempo, y todavía en la primera mitad del siglo XVI podemos encontrar representaciones de la misma en algunos contextos relacionados directamente con la muerte, como es el caso del Libro de Horas de Carlos $V$ con la escena del Encuentro de los tres vivientes.

Se afirma que estas tradiciones nacen en Francia e Italia, si bien existen dudas sobre la interpretación de programas iconográficos que pudieran demostrar que en Castilla existen ejemplos anteriores. Hay que tener en cuenta que los ejemplos que han llegado a nuestros días no tenían que ser los únicos, sino que el pasar del tiempo ha hecho que muchos vestigios se hayan perdido. La exposición en lugares selectos de La leyenda de los vivientes, como las pinturas murales en la iglesia de San Juan y San Pablo de Peñafiel (Valladolid), no sugiere que fuera un ejemplo casual.

La Danza de la Muerte en el territorio castellano se muestra en un códice de principios del siglo XV que se conserva en la Biblioteca de El Escorial ${ }^{12}$. En el propio texto se denomina a sí misma la danza del lloro. Son varias las ideas que pueden extraerse de la lectura de este texto y sumarse a las características ya expuestas en la descripción iconográfica. La tesis de este tema literario se centra en caracterizar la muerte a través de su figuración por medio de un esqueleto móvil que llama a danzar a sus víctimas. El acto de danzar se convierte en este escenario en el punto clave del tránsito entre este mundo terrenal y el espiritual, el momento del fallecimiento. Lo hacen a coro, y la muerte es la encargada de ir nombrando a cada individuo; este tétrico personaje va llamando uno a uno, a través de los diferentes sectores de la sociedad, a todos cuantos han de dejar su vida y aceptar el destino que les espera. De este modo se consigue equiparar a todos los hombres, sea cual fuere su rango, en este instante fatal. Es una visión tanto tétrica como sarcástica e irreverente y, sobre todo, muy diferente a todo lo anterior.

12 La danza de la muerte. Edición de Sabas MARTIN. Madrid, Miraguano, 2001. 
En la introducción se resume el argumento: «[...] Aquí comienza la Danza general, en que tracta cómo la Muerte avisa a todas las criaturas, que paren mientes en la brevedad de su vida, e que della mayor cabdal non sea hecho que ella meresce. E asimismo les dice e requiere que vean e oyan bien lo que los sabios predicadores les dicen e amonestan de cada día, dándoles bueno e sano consejo, que pugnen en hacer buenas obras, porque hayan complido perdón de sus pecados. $E$ luego siguiente, mostrando por experiencia lo que dice, llama e requiere a todos los estados del mundo que vengan, de su buen grado o contra su voluntad [... $]^{13}$.

Recalca a lo largo de la obra el mensaje que pretende exponer tan singular temática, esto es, la brevedad de la vida terrena, la igualdad de todos los estados sociales ante su advenimiento y la necesidad de mantenerse siempre alerta, sirviendo a Dios y cumpliendo sus mandatos para evitar la condenación y alcanzar la gloria eterna, pues Él es la verdadera salvación y capaz de superar incluso a la inminente muerte. Como ejemplo de esta idea recojo la siguiente estrofa: «[...] Dicen los que han de pasar por la muerte: / Pues que así es que a morir habemos / de necesidad, sin otro remedio, / con pura conciencia todos trabajemos / en servir a Dios sin otro comedio; / ca Él es principio, fin e el medio / por do, si le place, habremos folgura, / aunque la Muerte con danza muy dura / nos meta en su coro en cualquier comedio $[\ldots]\rangle^{14}$.

El autor aprovecha la llamada para exponer los distintos vicios o pecados en los que se encuentran los individuos, atendiendo a los tópicos y costumbres de la época, de acuerdo con las actuaciones inapropiadas que se imputa a cada oficio. Reprocha la inadecuada actitud de determinado individuo, y en el último verso llama al siguiente personaje, quien responde a la llamada de la muerte en la siguiente estrofa. Sirve, por tanto, de fuente para descubrir las actitudes típicas que identifican a cada uno de los oficios durante este periodo.

La cúspide de la jerarquía social, representada por reyes, arzobispos y obispos, entre otros, es acusada de conductas inmorales, contrarias a aquello que se esperaba; así mismo se hace referencia a algunos profesionales concretos, como los usureros o recaudadores, y a todas las etnias, representadas aquí por el rabí y el alfaquí, insistiendo en la igualdad, no sólo social sino también racial, ante la muerte. Se confiesan ellos mismos al tiempo que son llamados, bien alabando la buena vida que no desean perder, bien sabedores de que el modo en el que han vivido les conducirá a la pena eterna. Su llamada no es aceptada por ninguno, y todos ruegan poder permanecer más tiempo gozando de los deleites terrenales y alejados de la fealdad de su danza.

La muerte, por su parte, insiste en argumentos que le son propios y deben conocer todos los humanos; su danza es un acto ineludible y, además, es inminente y no atiende a criterios de edad, ni de rango social ni profesional, por lo que con-

13 La danza de la muerte, p. 8.

14 La danza de la muerte, p. 86. 
viene vivir haciendo penitencia: «[...] Lo que dice la muerte a los que no nombró: / A todos los que aquí non he nombrado, / de cualquier ley e estado o condición, / les mando que vengan muy toste priado, / a entrar en mi danza sin excusación; / non recibiré jamás exención, / nin otro libelo nin declinatoria, / los que bien ficieron habrán siempre gloria, / los que contrario, habrán dampnación [...] ${ }^{15}$.

Supone el fin de la vida mundana, la pérdida de los bienes terrenos y el momento de dar cuenta de las obras que durante su estancia en la tierra hayan efectuado, condicionando su destino, es decir la pena eterna o el infierno para quienes han pecado y sucumbido a los vicios, y la gloria eterna, la adscripción en el libro de la vida, para quienes han cumplido con su función y han vivido correctamente; el cura, el monje negro, el ermitaño y el labrador son tomados como ejemplos en la obra, advirtiéndose una evidente denuncia ético social contra los sectores más poderosos.

Dejando a un lado el tema iconográfico de la danza macabra, también en la literatura aflora esta nueva percepción sobre la idea igualitaria de la muerte a partir del siglo XV. Así lo refleja, entre otros, Juan de Mena en un diálogo con la muerte, en el que alude al tema de la igualdad ante ella de todos los individuos, diciendo que «[...] a todos convida, sordos, ciegos, mudos, donde olvidan los sesudos, sabios, rudos, esforzados [...]", y a la volatilidad de los bienes mundanales, que de nada servirán cuando llegue el momento de enfrentarse a ella. Insiste también en el lugar que cualquiera de ellos va a ocupar a partir de ese momento, es decir, sepultados o pobladores de cimientos. Continúa el poema enunciando grandes hombres que han muerto a lo largo de la historia, desde personajes del Antiguo Testamento como Salomón, reyes y emperadores de todos los tiempos, como Alejandro o Arturo, o míticos como Agamenón. Sirvan entonces estos individuos como ejemplo de aceptación del fin que a todos los seres humanos les espera. Dará igual la condición de la que sean, pues de nada les servirá ni el saber, ni el poder, ni las riquezas. Tras la muerte todos quedarán equiparados en el mismo orden, sin estado que los diferencie ${ }^{16}$.

En la obra de Jorge Manrique Coplas de Jorge Manrique a la muerte de su padre, el Maestre don Rodrigo, encontramos alusiones al tema de la igualdad en la muerte, que aparece así mismo en la danza macabra, que desde su llegada de tierras francesas ya se ha instalado en la cultura bajomedieval castellana. Claro ejemplo es la copla III, que dice: «[...] Nuestras vidas son los ríos / que van a dar en la mar, / qu'es el morir; / allí van los señoríos / derechos a se acabar / e consumir; / allí los ríos caudales, / allí los otros medianos / e más chicos; / allegados son iguales / los que viven por sus manos /e los ricos [...] "17.

15 La danza de la muerte, p. 86.

16 Juan de MENA, Laberinto de Fortuna. Edición digital. Biblioteca Virtual Miguel de Cervantes.

17 Jorge MANRIQUE, Coplas a la muerte de su padre. Madrid, Castalia, 1983, p. 48. 
En sucesivas coplas volverá sobre este tema, refiriéndose a personajes históricos del pasado, monarcas, diferentes representantes de la nobleza,...; no sólo alude al hecho de que la muerte los iguala a los demás hombres, sino también a otra de las tesis argumentales de sus coplas, que sus riquezas y sus bienes materiales de nada les han de servir, ni en la otra vida, ni para librar el destino final del ser humano que pasa por esta tierra y se esconde en el más allá.

Esta línea se sigue en otros escritos literarios de la Baja Edad Media, en los que se hace patente una personificación de la muerte en forma de un personaje al que se dirige directamente el narrador; se afirma que la muerte es consuelo para los que salvaron su alma antes de llegarles el momento, ya que, como cita ineludible, se espera siempre que llegue en buena situación para poder salvarse. Se apunta al sentido igualatorio de la muerte, enunciando series de personajes, que van desde el monarca hasta los labradores, que pasan por ella, sin que exista distinción de edad ni de riquezas; se apunta al consumo del cuerpo y de todo lo terrenal y mundano, y al sufrimiento que provoca a los seres queridos ${ }^{18}$.

\section{Espacio, identidad, muerte}

Existe una relación entre el espacio físico, la identidad y la muerte, que se materializa en el lugar de descanso eterno, el cementerio. La tumba individual supone un nuevo medio, permanente y atemporal, que mantiene presente el recuerdo del difunto tras el fallecimiento. Según el estudio de Ariès ya citado con anterioridad $^{19}$, en los siglos XI y XII el elemento simbólico de la tumba da un giro importante, ganando visibilidad e individualización, como mejor expresión de un nuevo modo de afrontar, representar y vivir la muerte. Para los estudiosos de estas conductas en las diferentes culturas y tiempos históricos, representa un hecho difícil de explicar, al menos las causas de este cambio. Los monumentos funerarios ganan importancia, tanto las representaciones iconográficas como las leyendas epigráficas y las efigies. Se convierten en un signo del cuerpo y, a su vez, en una forma de prolongación y representación de su identidad social, como resultado del interés de mantener viva su identidad, aunque ya no pertenezca al mundo terrenal.

La presencia de los muertos es constante y doble. El cementerio se convierte en una nueva representación de la communitas, y su traslado a él la forma de que el difunto se mantenga ligado a ésta; perder la posibilidad de ser enterrado en el cementerio supone quedar desligado de la comunidad. Si vamos más allá, podemos profundizar en la doble vinculación entre ambos grupos, los vivos y los muertos, pues se interrelacionan e intercambian favores; los cementerios se edifican en

18 Es interesante a este respecto la recopilación de poemas bajomedievales que se hace en el conocido como Cancionero de Baena: Cancionero de Juan Alfonso de Baena. Madrid, Visor libros, 1993 (véase como ejemplo el poema nำ510, p. 353).

19 Philippe ARIĖS, Historia de la muerte en Occidente. Desde la Edad Media hasta nuestros días. 
torno a la iglesia, intramuros de la ciudad; por lo tanto, son cercanos a los habitantes de la ciudad y a la vida cotidiana, y se hacen visibles en todo momento. Por la solidaridad que mueve al cristiano y vecino medieval, éste mantendrá un riguroso deber de velar, mediante misas y oraciones, por el alma del difunto, a la vez que prepara la suya propia para cuando llegue el ineludible momento. Aunque la necesidad de destacar un recinto donde repose el fallecido es un hecho social y psicológico dentro de la conciencia occidental que aún perdura, durante el periodo bajomedieval surgieron ecos de cambio entre algunos fieles, dando muestras de un planteamiento más innovador. Es el caso de Vicente Ferrer, quien aboga más por el elemento en el que se sitúe el difunto que sobre el lugar propiamente dicho. Gana asimismo peso la forma en la que se produce el fallecimiento, es decir si se perece ahogado, quemado, o si el difunto es encontrado bajo tierra. Su punto de vista va ligado a su versión sobre la resurrección de los cuerpos. Por lo tanto, existen algunas variantes en las creencias que a este respecto se habían mantenido en la Alta y Plena Edad Media con respecto a lo que sucede en el siglo XV, como no puede ser de otro modo, al amparo de los cambios ideológicos que van a fraguarse en esta centuria.

Directamente ligado a causas religiosas y al pecado, el enterramiento fuera de sagrado suponía, además de una pérdida de favores salvíficos, una clara exclusión social; es un buen ejemplo de la importancia que tenía la buena muerte. Se teme a las almas de los individuos que no eran enterrados en sagrado, puesto que serían condenadas y no podrían descansar en paz en el paraíso celestial, por lo que se creía que podrían retornar al mundo de los vivos con el fin de conseguir la salvación de esta pena, o como espectros maléficos por su condición de pecadores. Algo similar ocurre con los infantes que fallecen antes de recibir el bautismo, que estaban condenados a vagar en el limbo; este es el motivo por el que se decide adelantar el bautismo al día siguiente del nacimiento, debido a la elevada mortalidad infantil y a la preocupación de que estos pequeños mueran como infieles, sin tiempo de abrazar la fe de Cristo.

La distancia física entre el cuerpo del difunto y un objeto o lugar sacro es relevante para obtener beneficio en el momento en el que sea juzgado. La intercesión de los santos se producía tanto en vida como después de ella, por lo que la cercanía a objetos o a lugares sacros era especialmente relevante. De este modo, el hecho de no poder descansar en lugar sagrado, en un cementerio, en una iglesia, o en otros centros de relevancia espiritual, como era toda Tierra Santa, traía enormes y terribles consecuencias para los finados. Por lo tanto, el lugar físico de descanso tras la muerte tenía también una gran importancia de cara a lograr la salvación. Esta idea se desarrolla a partir de la creencia de los fieles en que, llegado el día del juicio final y la resurrección de los cuerpos, quienes se encontraran en lugares de mayor primacía espiritual tendrían más facilidades para salvarse. Aquí entra en escena el valor del cuerpo físico en la época medieval, y la relevancia del lugar de enterramiento. 
La exclusión de enterramiento en lugar sagrado se vincula a pecados graves y a penas sin remisión, que deben ser adecuadamente puestas en conocimiento de los fieles cristianos para no caer en tamaño castigo. Así, en el Libro de las confesiones de Martín Pérez, escrito en el primer cuarto del siglo XIV, el autor dedica un apartado completo a esta cuestión, bajo el título quales personas pecadoras non deven aver sepultura ${ }^{20}$.

Un claro ejemplo moral e iconográfico lo encontramos en la Cantiga número XXIIII de la obra de Alfonso X. En ella se narra cómo un clérigo tahúr y ladrón, pero muy devoto de Santa María, fue enterrado fuera de sagrado por los demás clérigos. La Virgen intercede por él y se le aparece en sueños al prior, quien desentierra el cuerpo del hermano, descubriendo en su boca una flor de lirio, hecho que identifican como una señal mariana. Finalmente, trasladan al finado y lo entierran en la iglesia muy honradamente.

Por todo ello, se pretende evitar que los fieles cometan actos inapropiados: el suicidio, la usura, el robo, fallecer excomulgados, la muerte en pecado mortal, el homicidio voluntario o aquel provocado por los efectos de la embriaguez; los que no se arrepienten y, por tanto, no confiesan sus pecados antes de la muerte, y aquellos que no se han confesado a lo largo del año en el que fallecen son, junto con los que perecen en justas, quienes quedan exentos de recibir santa sepultura. El riesgo a morir en una de estas condiciones parece elevado si atendemos al hecho de que quienes mueren en pecado mortal son todos los que cometen actos en contra de los mandamientos de Dios, de pensamiento, palabra u obra, además de los que viven en pecado criminal, pues todos los pecados criminales son mortales e graves. Aquí se incluyen la simonía, la herejía, la apostasía, el cisma, el sacrilegio, el perjurio, el adulterio, el homicidio, el hurto, la traición, la conspiración y la rebeldía. La lista es extensa, por lo que los habitantes del Medioevo debían andar con pies de plomo si querían mantener el derecho a descansar en suelo sagrado.

Para acrecentar el temor, las penas se hacen extensibles a los clérigos que osen dar enterramiento $u$ ofrendas a quien haya finado sin derecho a recibirlas. Especialmente significativos son los modos mediante los que se avisa al clérigo de quién no debe ser enterrado si no cumple las condiciones requeridas: quando finaren, que non ayan sepultura eclesiástica, nin sepultura en el çementerio de la iglesia, nin sepultura con los fieles christianos, entre otras. Alude al valor de tierra santa que ostenta el recinto, así como la pertenencia a la comunidad, negándole ambas.

Alonso de Cartagena, en su Doctrinal de los Caballeros, insiste en el carácter temerario, osado e imprudente de los caballeros medievales, en no pocas ocasiones faltos de preparación intelectual, con un gran afán de rapiña en las postrimerías de la institución, y muy aficionados a las justas y torneos, que eran otras de

20 Martín PÉREZ, El Libro de las Confesiones. Una radiografía de la sociedad medieval española. Madrid, Biblioteca de Autores Cristianos, 2002, p. 42. 
las actuaciones de estos nobles enormemente criticadas y sancionadas por el clero $^{21}$. Fueron actos muy demandados por los caballeros para probar su valía, su honra y su orgullo, pero muy criticados y condenados por el mundo eclesial, por las nefastas consecuencias que estas contiendas solían tener para los participantes; heridas, mutilaciones e, incluso en ocasiones, la muerte, eran el resultado de estos actos, que se celebraban sin ningún beneficio, salvo la vanagloria personal y el entretenimiento de los allí presentes. Por este motivo, también se enunciaron normas en su contra, siendo la más grave la prohibición de ser enterrado en santo lugar aquel que hubiera fallecido tomando parte en alguno de estos torneos. Esta sentencia equipara morir en estos actos al suicidio, es decir a la depravación que supone en el mundo cristiano el morir por propia mano y voluntad; unos y otros recibían la misma pena de no poder obtener sepultura en camposanto. Así se demuestra en la sentencia que aparece en la obra de Pero Rodríguez de Lena titulada El passo honroso de Suero de Quiñones, en referencia a la muerte de Asbert de Claramunt, un caballero que fue muerto durante esta lid $^{22}$. Queda esta condición demostrada en el Doctrinal de Caballeros de Alonso de Cartagena, en concreto en la Introducción del quinto capítulo, titulado De la Divisa de la Banda y de los torneos, en la que el autor expone la prohibición espiritual que al respecto pesa sobre justas y torneos, diciendo que «[...] el derecho canónico en uno de los concilios que se hicieron en San Juan de Letrán, expresamente veda los torneos, privando de sepultura a quien torneando muere [... $]^{23}$.

Esta actitud, y la dedicación del tiempo a torneos y justas, alejan al hombre de armas del empleo de la violencia para aquello que justifica el mundo religioso, que no es más que la defensa del cristianismo contra los enemigos de la fe, y se sanciona todo lo que de esta realidad se aleje.

En la misma línea se mueve Francesc Eiximenis en su Tratado de Caballería, escrito en catalán algunos años antes que el de Alonso de Cartagena (último cuarto del siglo XIV, según apunta José Luis Martín), en el que recalca la prohibición de estas batallas personales, tanto por tratarse de algo molesto para Dios por cuanto debe decidir quién gana y quién no, como porque quienes lo cometen corren el riesgo de morir, lo que se podría interpretar como un suicidio, y porque no siempre vence quien lleva razón, como ocurre en el caso de las luchas entre sarracenos y cristianos ${ }^{24}$.

Otro grupo predispuesto a la pena de no ser enterrado en sagrado es el de los presos y condenados. Como respuesta a esta realidad, encontramos a mediados del siglo XIII el surgimiento de agrupaciones o Hermandades de Misericordia ${ }^{25}$, en-

21 Alonso de CARTAGENA, Doctrinal de caballeros; Tratado de la guerra; Dichos de Quinto Curcio. Edición de Noel Fallows. Ministerio de Defensa, 2006.

22 Idem, p. 26.

23 Idem, p. 311.

24 José-Luis MARTÍN RODRÍGUEZ, «Tratado de Caballería de Francesc Eiximenis», en Norba Revista de Historia. Universidad de Extremadura, no 16, 2003, p. 311.

25 La más antigua conocida está datada en Jaén en 1242. 
cargadas de recoger los cadáveres de los reos y darles sepultura en los Cementerios de los Ajusticiados.

\section{LA CONCIENCIA DE UN MÁS ALLÁ DE LA MUERTE}

Una característica de enorme calado en la mentalidad medieval es la idea de una justicia que va más allá de la muerte, infligiendo castigos que el difunto hubiera tenido que sufrir en vida, o atentando contra la honra o la memoria, que podía ser manchada aunque el interesado ya no estuviera de un modo físico en el mundo. Para explicar estas afirmaciones sirve de gran ayuda enunciar lo que acontecía a algunos de los condenados por la Santa Inquisición cuyas sentencias se ejecutaban post mortem; aunque el procesado hubiera muerto inocente y enterrado como tal, si se probaba su culpabilidad, sus restos eran exhumados y llevados a la hoguera como un penado más.

Las sentencias eran ejecutadas sobre los difuntos condenados, del mismo modo que habría ocurrido si siguieran con vida. Con este simbolismo se consiguen varias finalidades. En primer lugar, es un signo ejemplarizante para el resto de los cristianos, puesto que induce al temor del castigo más allá de la muerte, de la imposibilidad de salir airoso si se cometen pecados en vida y de cómo tanto sus restos mortales como su linaje pagarán sus culpas aunque los juzgados ya no estén en este mundo; el pecador nunca descasará en paz. En segundo lugar, es una muestra más del miedo en la Edad Media a la pérdida de la identidad, la honra y la fama, algo que no se limitaba a una persona en concreto y mientras viviera, sino que abarcaba toda la eternidad y se hacía extensiva a su familia. En tercer lugar, es una imagen del poder que ostenta el Santo Tribunal, que puede incluso sentenciar y condenar a quien ya no está en este mundo, demostrando igualmente que este pecador no ha sido salvado por Dios, y que la muerte eterna y el castigo eterno le han sido impuestos. Además, por supuesto, del beneficio económico que se obtendría de los bienes incautados a algún condenado ya fallecido.

Son numerosos los casos de condenas post mortem que pueden encontrarse en la documentación inquisitorial castellana de fines de la Edad Media y comienzos de la Edad Moderna, y sirven de ejemplo de esta realidad algunas de las disposiciones que se contienen en procesos inquisitoriales promovidos a fines del siglo XV contra judeoconversos vecinos de Ciudad Real que fueron acusados de judaizar. Es el caso del reo Juan Gonçales Escogido ${ }^{26}$, difunto, quien fue condenado en septiembre de 1484; al inicio del procedimiento inquisitorial, el Santo Tribunal citó a «[...] sus hijos, herederos e parientes, para que paresçiesen ante ellos a defender la persona e huesos e bienes del dicho Juan [...]” del delito de herejía y apostasía

${ }^{26}$ Esta sentencia es una de las que aparece recogida en la obra de Haim BEINART, Records of the trials of the Spanish Inquisition in Ciudad Real. Jerusalem, The Israel Academy of Sciences and Humanities, 1974-1985, 4 vols. (en concreto en el vol. I). 
del que estaba acusado, especialmente si alguno de ellos tenía derechos sobre algún bien que hubiera sido anteriormente propiedad del acusado, so pena de ser igualmente acusado de los mismos delitos.

Cuando los acusados ya difuntos resultaban inculpados, se ordenaba la confiscación de sus bienes, se decretaba su excomunión de excomunión mayor, eran declarados herejes y, en consecuencia, y con arreglo a la gravedad de los delitos cometidos, se ordenaba «[...] desenterrar adondequiera que estuviesen sus cuerpos e quemar a ellos e a sus huesos [...]". Aunque se insistía en que al llevar a cabo esta acción era fundamental garantizar el respeto por los buenos finados, por lo que «[...] deven ser desenterrados e echados fuera si se pueden conosçer entre los huesos de otros fieles christianos, si non, mas vale que finquen [...]”.

Esta afirmación, que parece tautológica, enfatiza en el acto por el cual no sólo se van a quemar simbólicamente los restos físicos del condenado, sino que la condena se va a extender a todo lo que representa ese individuo, a su verdadera identidad terrena, es decir a su fama, memoria y honra, dando por supuesto que su alma ya había sido condenada por Dios desde el momento de su muerte, como pecador, hereje y apóstata. Su nombre es leído en el cadalso y, tras asegurarse de que sus huesos pueden ser desenterrados sin hacer perjuicio de otros fieles que allí descansen, los restos son exhumados "[...] e sean públicamente quemados porque perezcan ellos e su memoria con ellos, e sean quitados de la vid e çepa en que están pues fueron herejes [...]».

En definitiva, los condenados por la Inquisición sufrían diversas penas espirituales y terrenales, como la excomunión mayor papal y la confiscación de bienes, que eran aplicados a la cámara y fisco de los reyes. Por lo tanto, perdían el derecho a descansar en tierra sagrada, su memoria era condenada y sus bienes materiales pasaban a llenar las arcas inquisitoriales. Pero dejando a un lado el fin lucrativo, esta sentencia, al igual que otras de este tipo, reflejan claramente la mentalidad de los individuos castellanos de finales de la Edad Media. Este castigo no se limita a los inculpados propiamente dichos, sino que se hace extensivo a sus familiares, y tal es el temor que provoca que es utilizado como una dura amenaza. En el proceso promovido contra Catalina de Zamora se afirma que un fraile, pretendiendo intimidar a la acusada, le habría lanzado la siguiente amenaza: «[...] doña puta vieja, si los inquisidores aquí vienen, yo vos haré quemar, y a vuestras hermanas por judías, y a vuestra madre yo haré sacar los huesos y quemarlos porque era judía [...]”.

En definitiva, vemos que para el individuo medieval la justicia no tiene límite, ya que la muerte en sí no es el fin. Y no solamente para el juicio divino, sino también para el civil, ya que tiene la posibilidad de ejecutar sentencias no sólo a vivos sino también a muertos, una capacidad que representa, qué duda cabe, un gran poder. 


\section{La memoria y la identidad después del fallecimiento}

La importancia que se concede a la memoria tras la muerte no es algo exclusivo de época medieval, sino que se hace extensivo al ser humano en cualquier tiempo y lugar. Esto nos conduce al miedo que existe al olvido de uno, a no dejar huella del paso por esta existencia, a escapar del recuerdo de quienes habitan este mundo, a la desaparición total que esto supone. En numerosas civilizaciones, sirva de ejemplo la egipcia, uno de los peores y más severos castigos que se aplicaba era la eliminación de todo aquello que vinculara a un individuo con el ámbito terrenal, siendo así negada su existencia o, al menos, haciendo imposible que fuera probada por sus descendientes. Esta preocupación, ligada a la salvación del alma, se materializa en las cláusulas testamentarias en las que se estipulan misas y celebraciones de aniversario, que si bien tienen una prioritaria finalidad religiosa, no dejan de ser también un medio para mantener vivo el recuerdo del finado, del mismo modo que lo hacen las inscripciones en los sepulcros y lápidas, los honores, etc. Esta idea también puede deducirse de las descripciones de las penas infernales, en las que aparecen fauces que devoran al reo, o en los adjetivos que se utilizan a la hora de definir el propio infierno.

Ligado a este valor social y al miedo que provoca el escarnio, junto a la importancia de la memoria y del mantenimiento de la identidad, incluso después de la muerte, es significativo el ceremonial que tiene lugar durante los autos de fe inquisitoriales con respecto a los culpados que no pueden haber sido detenidos. Si alguno de los condenados al fuego no estaba presente, se quemaba su efigie dentro de un acto plagado de simbolismo. Incluso van más allá, de forma que, como ya se ha explicado anteriormente, a los procesados que ya habían fallecido se les exhumaban los cuerpos y se quemaban sus huesos junto con el resto de inculpados, $y$ ante los ojos de la comunidad.

Podemos señalar algunas sentencias recogidas en las actas del Santo Tribunal. Se trata de aquellas en las que el inculpado se encuentra desaparecido de la justicia, algo que no era infrecuente dado el temor que provocaba la Inquisición, de forma que no eran pocos los que dejaban todos sus bienes con la finalidad de escapar. En estos casos, y al igual que ocurre con los acusados fallecidos, la aplicación de la pena cobra un valor simbólico, ejecutándose sobre una efigie que encarna al imputado. Es el caso, entre otros, de Sancho de Çibdad y María, su mujer ${ }^{27}$, que lograron huir días antes de la llegada de los inquisidores a la ciudad. Tras el proceso, fueron condenados por los cargos que se les imputaban de cumplir en secreto con la ley de Moisés, así como de rebeldía por no presentarse a las reiteradas llamadas del tribunal, aplicándoseles las penas habituales en este tipo de delitos: excomunión mayor, confiscación de bienes, todas las demás penas espirituales y temporales habituales en estos casos, y, finalmente, la hoguera. En au-

27 También recogida en la obra antes mencionada de Haim BEINART, Records of the trials of the Spanish Inquisition in Ciudad Real, vol. I. 
sencia de los condenados, expone el escrito de la sentencia que «[...] relaxamos sus estatuas presentes en las que sean executadas las dichas penas [...]”. A partir de ese momento, los ajusticiados perdían cualquier atisbo de identidad. La misma suerte corrió el converso Juan González Panpan, quien tampoco había podido ser detenido, por lo que se dice que «[...] ejecutan la sentencia en una estatua que hacemos traer en su nombre para quemar, queda abierta la posibilidad si tienen la oportunidad hacer justicia en aquella ciudad e villa e lugar donde fuera haIlado [...]”. Pero la quema en efigie de los condenados no supone dejar sin aplicación el verdadero castigo, el cual queda pendiente para si pudieran ser hallados los condenados; esto es lo que sucede con los antes citados Sancho de Çibdad y su mujer, que fueron ejecutados en Toledo tras ser hallados y detenidos en el puerto de Valencia ${ }^{28}$.

Cabe preguntarse si esta forma de actuar era mero simbolismo ejemplarizante o si, por el contrario, obedecía a una creencia real en la posibilidad de causar daño tras la muerte física, algo que es común a otras muchas culturas. Lo que es innegable es la mancha que supone para la memoria del finado y para la de todos sus descendientes, lo que resulta especialmente negativo para el individuo medieval.

\section{Los castigos infernales}

Al tratar el tema del temor a la muerte y la pérdida de identidad, es necesario hacer referencia al infierno y las penas infernales, uno de los temas básicos y especialmente recurrentes en el mundo religioso. El infierno es representado iconográficamente en portadas y frescos de iglesias a lo largo y ancho de la geografía castellana, y en periodos cronológicos diferentes, si bien con ciertas variaciones. Muestra de ello son la portada de la catedral de León y las pinturas murales de la ermita de Santa Eulalia en Barrio de Santa María (Palencia). En ambas se representa el infierno con un caldero al fuego, que reavivan mediante fuelles para que no se agote en ningún momento, y con una serie de monstruos que son quienes ejecutan los castigos y torturas a los condenados, antes de que desaparezca todo rastro de ellos para siempre al ser devorados por las fauces. La iconografía del infierno relacionada con seres monstruosos y con fuego, propia de la imaginería cristiana, es común a muchas otras culturas, por el profundo simbolismo de este elemento; también es común el paralelismo entre infierno y un monstruo de enorme cabeza que devora las presas que a él van a parar. Las penas padecidas acentúan la noción de sufrimiento y tortura, del dolor que se padece en este lugar; así la cabeza que engulle, que causa la desaparición total del universo, aunque en realidad esta imagen parece contradecirse con la idea de castigo eterno.

28 Fidel FITA, «La Inquisición toledana. Relación contemporánea de los autos y autillos que celebró desde el año 1485 hasta el de 1501», en Boletín de la Real Academia de la Historia, XI (1887), pp. 289-332. 
Las fauces o la cabeza que engulle son una representación de un castigo de carácter canibalista. Antropológicamente, puede representar diversas realidades, ya que existen diferencias dependiendo del motivo: si se trata de un ritual funerario y el cuerpo que van a engullir pereció por causas naturales; si forma parte de actos violentos, guerras, luchas, que consistan en comerse a sus enemigos; o si, por el contrario, se corresponde con un símbolo religioso, a modo de sacrificio. Entre este último caso encontramos el ejemplo más notable, porque compone uno de los rituales simbólicos de mayor peso en el cristianismo, y que se desarrolla en el ámbito espacio-temporal que ocupa nuestro estudio: la Eucaristía. También figura en las penas infernales a través de las fauces del infierno devorando a los condenados. Esta temática heredada se difunde en la Edad Media sufriendo transformaciones hasta finales del periodo.

La práctica caníbal dentro de la sociedad medieval no está probada en ningún caso; sin embargo, los temores a que se llegue a la misma afloran en los momentos de crisis en toda la geografía europea. Los rumores de actos de este tipo se difunden, haciéndose referencia a mendigos que desaparecen de las calles o a tumbas recientes profanadas; sin embargo, no nos han llegado datos fehacientes de tales hechos. Somos conscientes de que el instinto de supervivencia del ser humano puede alcanzar extremos inimaginables en situaciones adversas, y el hambre es un mal demasiado presente durante el periodo medieval, en algunos momentos con una gran crudeza, como en la crisis de la decimocuarta centuria.

Desde el punto de vista literario, las penas infernales y el infierno se presentan siguiendo estos mismos cánones, insistiendo en su carácter terrible y tormentoso, su ubicación en el interior de la tierra y las alusiones a la mitología clásica en las descripciones del infierno, exponiéndose todo ello tanto iconográfica como literariamente.

En el Libro de Alexandre ${ }^{29}$, compuesto hacia mediados del siglo XIII, se hacen alusiones al infierno, a qué es y con qué finalidad se hizo, en contraposición a todas las grandezas creadas por Dios, dedicándole calificativos despectivos; así, se trataría de un lugar hambriento, espantoso, mal poblado, mal trecho, mal lugar, mal suelo, hecho por Dios para los malos, no puede entrar la luz, siempre en tinieblas, rodeados de muros de azufre muy fuertes, muchas y malas serpientes acechando a las almas constantemente, son insaciables, muertas de hambre, no hay flores, malos olores, lugar donde se encuentran los vicios... En definitiva, una suma de todo aquello que provoca asco y pena.

Además, se mantiene la idea jerárquica del infierno. Las almas condenadas se disponen en diferentes estratos: arriba, medio y profundo ${ }^{30}$, dependiendo de la actitud cristiana, de los pecados, y matizando en la idea de condenación directa para

${ }^{29}$ Libro de Alexandre ( $c^{\underline{a}}$ 1240). Edición de Jesús CAÑAS. Madrid, Cátedra, Letras Hispánicas,

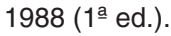

30 Idem., p. 104 
los infieles. Esto es, en la zona media del infierno se encuentran las almas de los judíos, siempre condenadas, pero menos que los malos cristianos, quienes por su alevosía serán más duramente castigados. Este hecho se mantiene ligado al concepto que se desarrolla en diversos penitenciales, confesionales y obras dogmáticas acerca de los diferentes deberes de cada individuo dentro de la sociedad. En este sentido, los castigos guardan relación con las obras realizadas y con lo que se espera de ellos por su condición social. Este pensamiento se hace extensivo a otras obras de diversa tipología y temática.

En el Libro de Alexandre también se alude a este hecho, afirmando que en el infierno se respeta un orden de castigo: «[...] allí arden las almas por el mal que fizieron, unas más, otras menos, segunt que mereçieron; sienten menos de pena las que menos fallieron, sufren mayor lazerio las que peor bivieron [...] mas non sienten sus penas todas igüalmente [...] ${ }^{31}$. Lo mismo ocurre con las almas de los niños que mueren sin ser bautizados; son numerosas las menciones al destino de éstas, ya que fallecen sin ser libradas del pecado original por este sacramento: "[...] las almas de los niños que non son bateadas, que son por el pecado original dampnadas, non arden con las otras, están más apartadas, pero en grant tiniebra, de luz desfeüzadas [...], ${ }^{32}$. Preocupación evidente y miedo lógico de los padres, si tenemos en cuenta las elevadísimas tasas de mortalidad infantil de este periodo. Esto explica la necesidad y el deseo de que los pequeños reciban el bautismo lo antes posible.

En la percepción de los tres espacios extraterrenos que se desarrolla en el siglo XIV apreciamos los cambios ideológicos que se han fraguado durante la expansión de la centuria anterior, paralelos al auge y la estabilidad económica, política y social, que propicia la transformación de las mentalidades predominantes en ese periodo. La visión que refleja Dante Alighieri en la Divina Comedia ${ }^{33}$ es diferente a todo lo anterior, y presagia el nuevo pensamiento que se aproxima. En primer lugar, el paraíso se presenta como el lugar en el que se alcanza el conocimiento de Dios, su visión y contemplación, a través de la gracia que se otorga al cristiano merecedor de tamaño galardón. Es una concepción más cercana a la filosofía clásica que a los estereotipos anteriores en los que se describen paraísos celestiales. Sirva de muestra el hecho de que, en la obra del florentino, quien acompaña a Dante en su viaje es el propio Virgilio.

Lo importante en los tres espacios que describe es la jerarquización que hallamos en cada uno de ellos, y el lugar que se ocupa es resultado de los méritos que en vida se han llevado a cabo. Son círculos que descienden y llevan a distintas cavidades, en las que habitan diferentes personajes. Así mismo, la consecución de la gracia, la presencia ante Dios, ha ido ganando individualidad a lo largo del periodo medieval, y adquiere en este ideal su máximo grado. Cuando comienza en la

31 Idem., p. 536, estrofas 2413 y 2414.

32 Idem, p. 536, estrofa 2420.

33 Dante ALIGHIERI, Divina comedia. Madrid, Cátedra, 2007 (1ำed. 1988). 
península la expansión de los dogmas cristianos a través de Biblias y Beatos, a fines del primer milenio, se aboga por un Juicio Final colectivo, común para la totalidad de la cristiandad, con Cristo a la cabeza; esta idea no se abandona, y en muchos ámbitos se mantiene, se modela y se perfecciona. Sin embargo, con el paso del tiempo, gana importancia la idea de la valía personal, los actos que cada individuo ejecute en su vida terrena, pues será juzgado con arreglo a ellos; como individuo integrante de una comunidad a la que debe permanecer ligado, y en la que juega un papel determinado por su posición, su expulsión es el mayor de los castigos. El cielo terrenal alberga la gloria eterna; en la Biblia, Jesús y la Virgen se elevan. A lo largo de la Edad Media, los relatos en los que se asciende al reino de los cielos, o metáforas similares, son frecuentes. Es la relación elevación-conocimiento-sabiduría que se desarrolla en otras muchas religiones, como, por ejemplo, la levitación en los ritos ascetas. La relación de este espacio, el cielo, y la divinidad se extiende a las señales que se proyectan desde él: fenómenos celestes, tormentas, falta de lluvias, etc., todo aquello que puede ser interpretado de un modo positivo o negativo pasa a convertirse en una acción divina, en una muestra de agradecimiento o de ira contra la población humana.

\section{El estado en el momento del paso a la otra vida}

En el periodo que nos ocupa surge la noción de la existencia de una conexión entre vivos y muertos, desde dos realidades distintas. Por un lado, con la revolución del mundo urbano, el espacio físico de enterramiento se sitúa dentro de los límites físicos de la ciudad, es decir dentro de los muros que dotan de identidad al habitante, salvo excepciones como en el caso de las minorías étnicas. Los cementerios se sitúan junto a las iglesias, utilizando los muros de éstas para alzar su trazado, siendo lugares de paso y relevantes; en definitiva, ambos, vivos y muertos, deben convivir.

Otra realidad es la de los fantasmas, apariciones de difuntos, ánimas en pena, etc. La creencia en ellos es común en numerosas culturas, y está ligada a diversos tipos de ceremoniales que se ejecutan en todas ellas. Sin embargo, si analizamos las enseñanzas bíblicas, no queda lugar para la posibilidad de que los muertos vuelvan de sus tumbas salvo el día del juicio final, momento en el que todos resucitarán a la vez, algo que está cargado de complejidad y que conoce diferentes interpretaciones a lo largo del periodo medieval. Fernando Martínez Gil, en su obra La muerte vivida, recoge estas creencias medievales y las relaciona en el contexto del cristianismo con dos hitos: la materialización del purgatorio, tema controvertido al que Jacques Le Goff dedica un exhaustivo estudio ${ }^{34}$, y la institución del día de los difuntos ${ }^{35}$. Era común la práctica de ciertas costumbres tras el falleci-

34 Jacques LE GOFF, El nacimiento del Purgatorio. Madrid, Taurus, 1981.

${ }_{35}$ Fernando MARTÍNEZ GIL, La muerte vivida. Muerte y sociedad en Castilla durante la Baja Edad Media, p. 123. 
miento de un ser querido, con el fin de que su alma no quedara entre los vivos y para facilitar su paso al más allá, como tapar espejos, abrir ventanas, quemar o lavar ropas, muchas de las cuales se han mantenido vigentes hasta hace unas décadas, lo que es una prueba evidente de su arraigo en la mentalidad colectiva.

Pero las apariciones no se limitan a finados, sino que también se han recogido en las fuentes visiones religiosas de santos o de la propia Virgen. Además, se mantiene la creencia en procesiones nocturnas de ánimas, conocidas como la Hueste Antigua (Estantigua), la Santa Compaña de tradición galaica, o el Ejército de Odín en la tradición germana. La finalidad de estas procesiones de ánimas podía ser atrapar las almas de quienes encuentran a su paso, un fallecimiento inminente temido en el periodo que nos ocupa, o avisar a uno de los miembros de una familia de una muerte cercana, concediendo tiempo para la preparación de una buena muerte. En cualquiera de los casos, era una escena que provocaba espanto entre los espectadores.

La convicción de los habitantes del Medioevo de la posibilidad de volver tras la muerte al mundo material de los vivos, a la que he hecho anteriormente alusión, es una creencia de tradición pagana ancestral y que se mantuvo durante bastante tiempo en ciertos sectores del cristianismo. Se trata de individuos cuyas almas no han encontrado descanso y que se presentan ante los mortales por diversos motivos. El más habitual es el de reclamar a sus familiares oraciones o ceremonias con la esperanza de salvarse y obtener el glorioso galardón que no han obtenido tras su muerte, bien por perecer en pecado, bien porque su penitencia no fuera suficiente; también son errantes las ánimas de aquellos que no han podido ser enterrados en sagrado.

Es evidente que ni en la iconografía cristiana que alude a la muerte y al abandono del alma del cuerpo, ni en las palabras que se recogen en las fuentes escritas, queda lugar para la creencia en la posibilidad de fantasmas merodeando por los rincones de la vida cotidiana medieval; sin embargo, esta insistencia iconográfica y literaria puede reflejar un deseo de aleccionar sobre el fin del alma y, por lo tanto, evitar este tipo de ideas supersticiosas. Véanse, como ejemplo, las dos figuras angelicales que elevan las almas simbolizadas como niños en las representaciones cristianas durante el periodo medieval, tanto en contextos funerarios como religiosos, o las tétricas visiones de oscuros demonios esperando el abandono del cuerpo del ánima del fiel para capturarla, como predicaba San Vicente Ferrer y como se representaron en algunas de las Cantigas de Alfonso X, como ya se ha mencionado anteriormente.

\section{LA IMPORTANCIA DE LA IDENTIDAD Y LA MUERTE}

Estar vinculado a una comunidad es importante, necesario y tranquilizador; la identidad se hace necesaria para la instauración de valores y de deberes y, por 
ende, para el disfrute de derechos, que se manifiestan especialmente en los momentos de crisis, en las épocas de mayor necesidad. Las consecuencias del aislamiento o expulsión de un individuo trascienden a todos los ámbitos de la vida, tanto desde el punto de vista social como desde el económico y el religioso.

El individuo medieval se desarrolla desde el momento de su nacimiento en una posición social, económica y cultural que va a marcar su destino; es la base de su educación y de aquello que le espera en su futuro, de no ocurrir algún trágico suceso que altere esta realidad. Debido a las pocas posibilidades de cambio social, tanto de descenso cuanto más de ascenso, son conscientes del lugar que cada uno de ellos ocupa en el mundo y de aquello que esto conlleva en su vida y en su muerte. En definitiva, el hecho de que la vida del individuo medieval esté tan acotada no hace más que incidir en la necesidad de aprender y mantener una conducta particular desde el momento del nacimiento hasta la muerte. Conocer aquello que se espera de su posición en el mundo da seguridad, tanto en el aspecto laico como en el espiritual. Por lo tanto, la pérdida de esta posición, y sus consecuencias, provoca una enorme incertidumbre, que acabará desembocando en un profundo miedo.

A medida que avanzamos en el tiempo, cada hombre va adquiriendo valor por sí mismo, por sus acciones, por su capacidad de decisión y alteración del curso de su vida y su futuro, en el ámbito civil y en el religioso. Esta preocupación por su persona, unida al contexto de constante angustia que se vive en los periodos medievales, empuja al individuo en los tiempos de la Plenitud medieval a la agrupación, especialmente para hacer frente a ciertos aspectos de la vida cotidiana como enfermedades, catástrofes naturales o la muerte. Gremios, cofradías, hermandades, órdenes religiosas y de caballería, surgen con fuerza en la Plena Edad Media; así lo afirma Walter Ullmann cuando dice que «[...] la necesidad de unirse $o$ asociarse se explica por sí misma, si recordamos debidamente que la Edad Media se caracterizó por el sentimiento de inseguridad y por la carencia de una protección eficaz. Basta observar la debilidad de los medios de protección privada y la tentación que ello suponía para aquellos que estaban en posición menos afortunada; tampoco resulta difícil darse cuenta de los estragos que causaban las enfermedades y las catástrofes naturales y de que no había idea de seguridad ni de ningún otro tipo de recurso para contrarrestar tales efectos[...]”36. Sin duda, esta frase recoge a la perfección la idea de ser social para el hombre medieval, la identidad que esto llevaba implícito y el por qué de la importancia para el buen desarrollo de su vida y, por ende, del miedo a perderla que ello conlleva. Los hombres se agrupan con el fin de sentirse más seguros y protegidos, además de recibir con ello esa identidad. Sin embargo, esto les genera una serie de deberes, no únicamente derechos. Los vecinos de un mismo barrio adquieren obligaciones de

36 Walter ULLMANN, Principios de gobierno y de política en la Edad Media, p. 220 (cita recogida por Francisco Javier FERNÁNDEZ CONDE, La religiosidad medieval en España. Plena Edad Media (siglos XI-XIII). Oviedo, Trea, 2005, p. 316). 
carácter social, de convivencia, especialmente en celebraciones, bien sean festivas o defunciones; normativas morales y económicas que se hacían palpables, en ocasiones disfrutándolas, en otros casos otorgándolas. Quedar excluido del colectivo supondría perder todo esto, perder todo tipo de ayuda, vivir en la inseguridad, en la soledad.

Uno de los cambios en los ideales que tiene lugar a lo largo de la Edad Media, desarrollándose en todo su esplendor en los tiempos bajomedievales, es el individualismo. La creciente importancia del individuo frente a la comunidad, a la colectividad, tiene una trascendental repercusión en la mentalidad de los individuos del Medioevo y, por ende, en la constitución de los miedos y sus símbolos. Es un hecho complejo, por lo que cabe hacer una serie de matizaciones para no caer en equívocos. El individualismo se refiere a la importancia del ser individualmente, como un átomo dentro de un conjunto de átomos que configuran un cuerpo. En los primeros tiempos no existe la conciencia individual, se es una comunidad, una familia, fuera de la cual la persona no tiene valor ni poder de decisión, de cambiar su destino, su suerte; todo le viene dado por el grupo en el que está integrado. A medida que el tiempo avanza se va fraguando el cambio de pensamiento, hasta alcanzarlo en su totalidad al final del periodo, donde se hace más patente. Cada persona es un ser único dentro de un grupo que le dota de identidad, forma parte de él, ocupa un lugar y función necesarios para el buen funcionamiento del colectivo.

Este individualismo en el ámbito de los designios de la persona no debe confundirse con el aislamiento personal de cada individuo. Todo lo contrario, es un hecho manifiesto dentro del ser humano como ser social la necesidad del hombre medieval de formar parte de un colectivo, de un todo, que lo dota de identidad. Fuera de éste, el sentido de su vida se disuelve y se siente perdido. Es uno de los grandes miedos del hombre medieval, y se refleja en todos los aspectos y realidades cotidianas; todos los miedos llevan implícitos, en mayor o menor medida, esta pérdida de identidad, especialmente a medida que avanzamos en el tiempo.

Cuando sorprende la muerte, es fundamental encontrarse libre de pecado, en conformidad con el estamento social al que se pertenece; porque la buena muerte a la que debe aspirar un caballero no es la misma que la de un eclesiástico o la de un campesino. Por lo tanto, si el miedo a la muerte, a morir en pecado o a perder la identidad son generales, sin embargo, el modo, el lugar o la propensión no son los mismos para el conjunto de la sociedad; así lo plasman las fuentes, reforzando ese ideal de distinción entre los habitantes del Medioevo, lo que queda evidenciado en manuales de confesión, penitenciales y doctrinales.

En fuentes de la época encontramos alusiones a la necesidad de mantener el estado, lo que nos revela la vinculación entre identidad y salvación. Así, por ejemplo, varios capítulos de Los Castigos de Sancho IV advierten de los peligros, diciendo: «[...] si sopieres bien escoger, departir y estremar los unos omnes de los otros, por aquí será muy loado el tu seso, el tu sentido, el tu entendimiento, el tu 
estado y los tus fechos y auras loor acabada en vida y en muerte, $y$, aun que el tu cuerpo muera, non morira la tu buena fama y beuira en pos de ti [...] ${ }^{37}$.

Hace igualmente alusión a la memoria que se gana con la buena muerte, como mencioné en el apartado referente al más allá de la muerte.

En el Libro de los Doce Sabios ${ }^{38}$, compuesto en época del monarca Fernando III el Santo, y que consiste en un compendio de las actitudes y comportamientos que han de exigirse a un buen rey, en su capítulo XLIX se aconseja al monarca: no temas la muerte, sino encomiéndate a buenas obras. Asimismo, en el capítulo LXVI, que pone fin a la obra, se define la vida del monarca tras su muerte y se valora cuáles han sido sus obras, poniéndose de manifiesto que la mayor de las honras está estrechamente ligada a la memoria e identidad; de este modo, y poniéndolo en palabras de dos de los sabios que aconsejan a lo largo de la obra, se dice que «[...] más conocido serás muerto que vivo. [...] Hasta aquí te loaban los que te conocían, y ahora loarte han los que no te conocen [...]”. Se alaba la valentía del monarca, pero a la vez se critica la temeridad; en este fragmento se hace notoria la influencia del pensamiento aristotélico en la interpretación de ambos términos.

El caballero, por su condición de defensor de la fe, está más cerca de la salvación eterna que otros laicos aunque, en contrapartida, se le exige más. El caballero debe tener en cuenta los preceptos expuestos en tratados para no cometer imprudencias que puedan costarle la vida terrena y espiritual. No son pocas las contradicciones que encontramos en el prototipo de caballero medieval con respecto a la salvación y a la buena muerte. Todos los fieles deben morir limpios de pecado para poder obtener la recompensa divina, lo que se consigue gracias a una buena vida y una muerte ejemplar. La confesión y el arrepentimiento antes de expirar el último suspiro son requisitos indispensables, por lo que han de realizarse antes de un enfrentamiento armado. Morir en la defensa de la fe de los cristianos les convierte en merecedores directos de la salvación, especialmente si la muerte tiene lugar en Tierra Santa; es ésta una máxima que, en un primer momento, utiliza el papado con el fin de obtener un cuerpo de luchadores numeroso, fiel y barato, que durante la Edad Media se generaliza en un sinfín de cruzadas y guerras santas. El premio es tan deseado que se eleva el número de combatientes y sus formas se vuelven temerarias, pues ansían más la recompensa que temor les provoca la muerte. Tanto es así que, con el tiempo, desde las esferas más elevadas del cuerpo eclesiástico se denuncia esta actitud, con el fin de detener esas conductas casi suicidas.

Una de las obras más señaladas de época bajomedieval en las que se refleja esta imagen de la nobleza es la colección de coplas que dedica Jorge Manrique a la muerte de su padre ${ }^{39}$. En esta obra, Manrique expresa su convencimiento de

37 Castigos y documentos del Rey Don Sancho. Edición de Antonio Rivera García para la Biblioteca Saavedra Fajardo, capítulo XVI, p. 79.

38 También denominado Tratado de la nobleza y lealtad (c a $^{-1237) . ~ E d i c i o ́ n ~ d i g i t a l . ~}$

39 Jorge MANRIQUE, Coplas a la muerte de su padre. Madrid, Castalia, 1983. 
que las obras que se efectúan en este mundo tienen su repercusión a la hora de obtener el galardón para la vida eterna. Al igual que viene dándose en las composiciones de las últimas décadas, el autor hace distinción de estados en relación con los actos y sus consecuencias. Para un noble caballero, como lo fue su padre, la lucha contra los moros es el deber mediante el cual obtener la salvación. Así lo sostiene en la copla XXXVI: «[...] El vivir qu'es perdurable / non se gana con estados / mundanales, / ni con vida delectable / donde moran los pecados / infernales; / mas los buenos religiosos / gánanlo con oraciones / e con lloros; / e los caballeros famosos, / con trabajos e aflicciones / contra moros [...] ${ }^{40}$.

En interesante destacar algunas de las ideas que se contienen en la obra de Jorge Manrique. Por un lado, la afirmación de que todo lo terrenal es pasajero y no tiene validez, de forma que se presenta la vida mundana como un medio plagado de perversión, sin otro sentido que el de la condenación y el pecado; por este motivo, insiste el poeta que se debe vivir atento y manteniendo una vida acorde con su estado, alejándose de estas trampas y efectuando las acciones que le den el pase a la verdadera vida, la que llega tras la muerte corporal. Manrique recoge en su obra el principio igualitario de la muerte para todos los hombres, pero matiza que no es igual en función de la distinción social, algo que contrasta con la iconografía de la danza de la muerte, en la que todos bailan juntos en corro.

Insiste, y no lo hace únicamente en esta copla, en la carrera de su progenitor como caballero que lucha contra el invasor e infiel. En el tiempo en el que escribe Manrique, los conflictos de relevancia en los reinos hispánicos se daban más por poder y riqueza entre la nobleza que contra los musulmanes, que ya habían sido reducidos a un pequeño espacio. Aún así, la imagen del caballero que lucha en defensa de la fe y del reino cristiano venía desde tiempo atrás alzando y dando sentido a su estado; la lucha en defensa de la fe era parte de la identidad de los caballeros, y eso les había hecho imprescindibles y valorados en la sociedad. Esta dedicación concedía a los caballeros una vía importante para la salvación de su alma, lo que los distinguía del resto de la sociedad. Mantener este prototipo y los ideales caballerescos, así como la alta alcurnia de la nobleza, es un ejercicio que se va a generalizar en el siglo XV, con el fin de prevalecer sobre otros grupos que surgían con mucha fuerza, como la burguesía, y al tiempo defender su identidad. El poder económico y social de este sector es reseñable dentro de la nueva realidad económica de base comercial y carácter urbano. Competía abiertamente con la nobleza, que había perdido relevancia debido al declive del mundo rural, a los cambios ideológicos y a las nuevas tácticas de guerra. La institución de la caballería pierde peso con la llegada de la pólvora, con el descenso de conflictos con los infieles y con los cambios en la conciencia religiosa. Del mismo modo, de la mano de la revolución urbana surgen otros colectivos con mayor o menor identidad propia: comerciantes, artesanos, aprendices, cargos civiles, o universitarios, quie-

40 Idem, . p. 65. 
nes aumentan su número y poder a medida que avanza el periodo y se hace más accesible la llegada al mundo académico. A cada uno de los oficios se acusará de ciertos actos y actitudes y, por el contrario, se alabará por otros, todos ellos con funciones y características identificativas propias. Esta nueva realidad social influye sobremanera en la concepción de la muerte y de todo lo que la rodea, incluidos los temores a su llegada.

Pero la propensión a vivir situaciones peligrosas y temidas no es exclusiva de los hombres de armas. Uno de los oficios que acarrea también frecuentes peligros es el de marinero, quien cuenta con un carácter particular por su valor, ya que es capaz de enfrentarse a los numerosos peligros de la mar: tormentas, naufragios, monstruos, ahogamientos, etc.

El miedo a la muerte en determinados momentos multiplica las acciones y creencias supersticiosas, más o menos criticadas por la Iglesia por su carácter contrario a los dogmas cristianos. Apunto como ejemplo el caso del parto en las mujeres. Debido a la elevada mortalidad de madres y de bebés durante el parto, se generaliza entre los habitantes del Medioevo la utilización de amuletos y nóminas, como cruces de Salomón o cintas de vírgenes que eran colocadas sobre la zona genital de la madre. Estos amuletos se utilizan con frecuencia, en cualquier momento en que se suscitase temor y en el que se pensara que corría peligro la vida del fiel, con ocasión de enfermedades, epidemias, guerras o hambrunas. Sabemos que el final del periodo coincide con la consecución de una nueva ideología conforme a los cambios que se han sucedido en todos los ámbitos. Dos hechos relacionados entre sí son relevantes: por una parte, la revolución del mundo urbano y sus consecuencias sociales, políticas y económicas, frente a la anterior tradición rural, y el aumento del porcentaje poblacional con acceso a una educación superior; por otra parte, desde el punto de vista filosófico, cabría mencionar la importancia que gana la razón. Esto invitaría a pensar que las gentes de este periodo se iban alejando cada vez más de los dogmas supersticiosos; sin embargo, todavía se alargarán en el tiempo. Estas costumbres son criticadas y juzgadas en tratados de hechicerías, especialmente en el siglo XVI, momento en el que se aviva el deseo de acabar con las creencias supersticiosas, la magia, la nigromancia y la brujería. Aparecen ahora diversos tratados en esta línea, como el Tratado de supersticiones y hechicerías de Fray Martín de Castañega ( $\mathrm{c}^{\mathrm{a}}$ 1529 ${ }^{41}$ o la Reprobación de las Supersticiones del maestro Pedro Ciruelo $\left(c^{a} \text { 1531) }\right)^{42}$. Esto refuerza la teoría de que muchos temores son paliados todavía con estos métodos.

El hambre es un factor de angustia constante en la sociedad medieval, que se acrecienta en periodos catastróficos con ocasión de malas cosechas, accidentes meteorológicos, guerras o crisis socio-económicas diversas. Fernando Gutiérrez Baños hace alusión a una idea que debemos tener en cuenta, y es que la mayoría

${ }^{41}$ Fray Martín de CASTAÑEGA, Tratado de supersticiones y hechicerías. Logroño, Ediciones de la Luna, 2001.

${ }_{42}$ Pedro CIRUELO, Reprobación de las Supersticiones. Madrid, Maxtor, 2005. 
de la población se encuentra en niveles de mera supervivencia ${ }^{43}$. Si se vive en los límites de la subsistencia, especialmente tras las grandes crisis del siglo XIV y hasta la recuperación de la siguiente centuria, es comprensible que exista una angustia constante a la muerte por inanición, al infanticidio pasivo por la imposibilidad de abastecer a todos los miembros de la familia, a la muerte violenta por robos, o incluso, al canibalismo.

Algo similar ocurre en el caso de las epidemias, las enfermedades o los accidentes que desembocan en la muerte. Si bien ningún individuo está libre de sufrir los efectos de las crisis, es indudable que la propensión es desigual. Los rituales y procesiones pseudorreligiosas, así como las medidas en extremo preventivas ante las epidemias, apuntan al pavor que ocasionan, si bien los medios adquisitivos de algunos les facilitan la huida ante la posibilidad de un contagio, frente a quienes son más propensos a enfermar, por su condición nutricional, por su falta de refugio o por su oficio. De ahí deriva parte de las mutaciones ideológicas que tienen lugar tras la gran peste de mediados del siglo XIV y, de forma particular, con ocasión de los brotes epidémicos que se suceden a comienzos de la siguiente centuria. La crudeza de la situación que se vivió durante estas terribles crisis transmitió los temores por ellas provocados a los descendientes de quienes las sufrieron en primera persona. Algunas descripciones de estos horrores sobrevivieron al tiempo y al espacio, como es el caso del Decamerón ${ }^{44}$. La narración de lo que se vivió en Florencia durante la peste, y la actitud de quienes convivieron con ella, refleja el espanto que padecieron y justifica las transformaciones en las actitudes ante el temor no sólo a la enfermedad sino, especialmente, a la muerte y a todo con lo que ésta se relaciona, y es de gran importancia en orden a explicar el devenir de las mentalidades en la Baja Edad Media. Advierte Boccaccio la igualdad con la que atenta el virus, sin atender a condición social, poder económico, edad o sexo; justamente la misma actitud que va a marcar la iconografía de la danza de la muerte.

El elevado número de muertos diarios derivó en falta de ataúdes y en la utilización del mismo féretro para trasladar a varios cadáveres, a veces incluso familias enteras. Las muertes eran tan frecuentes que los moribundos se encontraban desamparados al llegar a este trascendental momento. La peste impedía que se ejecutasen los rituales del modo más conveniente para el fiel cristiano: el duelo, el cortejo fúnebre, los llantos, los responsorios o el enterramiento. En fuentes castellanas sobre la peste de 1466 en Palencia aparecen alusiones al enterramiento de diez o doce personas en una misma sepultura, para expresar la cantidad de muertes y la rapidez con la que fallecían los infectados; al igual que en Florencia, se suspenden misas y exequias por no poder hacer frente a tantas demandas, suprimiendo también el doblar de campanas, lo que era habitual cada vez que fallecía

43 Fernando GUTIÉRREZ BAÑOS, «Los marginados en la pintura española de estilo gótico lineal», en Inés MONTEIRA ARIAS y otros, Relegados al margen. Marginados y espacios marginales en la cultura medieval. Madrid, CSIC, 2009, pp. 185-197 (véase p. 186).

44 Giovanni BOCCACCIO, Decamerón. Madrid, Cátedra, 2007 (1ำed. 1994). 
un vecino, alegando que al estar sonando sin cesar, entre otros males, provocaría depresión a los enfermos ${ }^{45}$.

Boccaccio se refiere a la situación moral que origina el temor a la peste, haciendo referencia de forma especial al estamento eclesial. Muchos de los encargados de velar por las almas de los moribundos enfermos emprendían raudos la huida, con el deseo de alejarse del contagio. Pero no son los únicos; y no sólo era una actitud deshonesta sino un peligro, ya que aumentaba el riesgo de expansión de la epidemia, por lo que se imponen sanciones para quienes intenten abandonar su lugar de residencia sin aviso, esencialmente a los sanadores y a los enterradores, cada vez más aterrorizados del contacto con los enfermos. Un recurso literario del italiano para oscurecer aún más el panorama e impartir tenebrosidad es la aparición de fantasmas que acechaban a los supervivientes, y que describe como sombras de los que han muerto, y no con aquellos rostros que tenían, sino con un aspecto horrible ${ }^{46}$; quién sabe..., lo que sí es cierto es que asistimos a los cambios que apuntaba anteriormente al referirnos a la actitud ante la muerte y su representación en las fuentes. En conclusión, la enfermedad no sólo es temida como tal, sino por las consecuencias negativas que ésta tiene ante un fallecimiento inminente.

\section{RECAPITULACIÓN FINAL}

En definitiva, podemos concluir afirmando que el temor a la muerte y a la pérdida de identidad se altera de la mano de la concepción de ambas realidades. Así como hemos mencionado que se trata de una población más habituada a la violencia, también debemos apuntar que la muerte estaba arraigada en el concepto de la vida del hombre de la Edad Media. El tabú con el que hoy nos enfrentamos a este tránsito no debió existir de igual modo en un momento en el que este paso era una realidad más cercana y aceptada con mayor naturalidad. La muerte llegaba en cualquier momento de la vida, y no eran pocas las decisiones que les obligaba a tomar. En momentos de crisis, un vástago podía ser sacrificado pasivamente para salvar al resto de los hijos (infanticidio pasivo), tarea que no debería ser fácil para los progenitores, pero que estaba a la orden del día en una sociedad en la que el equilibrio entre recursos y bocas que alimentar era indispensable. Aceptarlo como algo cotidiano e irremediable debería ser la mejor terapia para afrontar la vida. Las gentes fallecían en sus casas, y allí eran veladas y preparadas para las exequias por los propios parientes y vecinos. Los rituales ofrecían un aire dramático, como si el dolor real tuviera que ser revestido de algo teatral, lo que generaba críticas por parte del clero que defendía la muerte como el paso decisivo hacia la vida eterna, lleno de esperanza y fe. A finales del periodo, las actitudes inmorales de algunos

45 María Jesús FUENTE, «El impacto de la peste en una ciudad castellana en la Baja Edad Media: Palencia», en Publicaciones de la Institución Tello Téllez de Meneses, n . 59, 1988, pp. 415-432 (véase p. 424).

46 Giovanni BOCCACCIO, Ob. cit., p. 126. 
miembros del mundo eclesial son ahora las causantes de las quejas de las gentes hacia los religiosos, quienes deben velar por las almas de los creyentes.

El desconocimiento del más allá de la muerte provoca miedos en las sociedades desde tiempos ancestrales; Las penas infernales no sólo representan torturas y sufrimientos, sino un fin total del paso del hombre por el mundo, la pérdida de su ser, lo que las hace más abominables. La muerte física como desaparición del mundo incluye un temor a que el individuo desaparezca junto con su memoria, con la prueba de paso por la vida terrena, además de una angustia constante a la mala muerte, aquella que le cierre la puerta a su salvación; es el modo en el que se liga con la pérdida de identidad del individuo. El honor y el recuerdo tienen la función de mantener vivo al difunto, de la misma manera que lo hace la piedra, el sepulcro y la sepultura, así como los aniversarios, las misas o las loas.

Existe una identidad de grupo y una identidad individual; ambas son importantes y están relacionadas. La diferencia es notoria, especialmente en la Baja Edad Media, cuando se acepta el yo y todo lo que ello conlleva en el entramado medieval. Durante los primeros tiempos del Medioevo, el colectivo era el baremo por el que se regía la sociedad, quedando relegada la condición individual. Sin embargo, a fines del periodo, el individuo gana peso, aunque lo haga dentro y como parte de una comunidad. Así se refleja en las fuentes que en este periodo se redactan; cada individuo está obligado a cumplir unos deberes, y no hacerlo supone un riesgo para el alma. Un apunte de individualidad en la concepción del hombre medieval que representa el cambio que se está fraguando en la mentalidad de la sociedad, esta vez en relación con la muerte, lo encontramos en la Baja Edad Media en la Danza de la Muerte. El mensaje que se representa mediante esta iconografía es el de la igualdad de todos los hombres ante este momento crucial e inevitable. Esto refleja la equivalencia entre unos y otros llegada la hora de la muerte, por lo que los ritos, las acciones y los modos en los que se debe afrontar este tránsito deben ser los mismos para todos los pobladores del Medioevo, sea cual sea su condición. Se redactan obras en las que se aconsejan y recogen los medios para mantener en buen estado el alma, así como gana en relevancia la figura del confesor y del cura salvador de almas, quien debe cargar con el pecado del penitente. De la mano de esta nueva concepción se desarrolla otra iconografía totalmente distinta, la de la igualdad de la muerte y el gusto por lo tétrico, que se va desarrollando tras la crisis de la decimocuarta centuria. La danza de la muerte es, nuevamente, paradigma de esta visión. Su carácter irónico y burlesco no deja indiferente; ¿fue una escena temible o ridícula, aterradora o divertida en la mente del individuo medieval?

La pérdida de identidad se convierte en una muerte civil, una desaparición dentro de la comunidad y del mundo terreno conocido. Entre sus posibles consecuencias, el desvío del recto camino que da acceso a la gloria eterna marcado por el estado al que perteneció desde el comienzo de su vida. La muerte y la pérdida de identidad comparten muchas características, además de estar vinculadas, en mayor o menor medida, a otros miedos comunes a la sociedad medieval. 